\title{
Contemporary and Near-Contemporary Opinion of Louis XII, "Père du Peuple"1
}

\author{
RONALD S. LOVE
}

On 27 May 1498, King Louis XII, "Père du Peuple," was crowned in the cathedral at Rheims according to ancient French custom. Thus began one of the least studied reigns in French history. Too often regarded merely as an insignificant link in the chain that loosely unites Medieval and Renaissance France, the seventeen-year reign of Louis XII has largely been ignored. At the beginning of the last century, P.L. Roederer complained that "for three centuries we have only rendered to Louis XII's memory cold and equivocable homage." He was shocked by the lack of interest in the King and disgusted by the sterility of the few existing biographies. $\mathrm{He}$ was determined, therefore, to restore the King's memory to its former greatness, criticizing those who offered him only weak tributes for commonplace virtues and despising the "nearly contemptible eulogies" of others. ${ }^{2}$ Unfortunately, Roederer's work was not pursued. Only within the last decade has recent scholarship begun to take more interest in the period of Louis' reign; however, very little attention has been devoted to Louis himself. ${ }^{3}$ Consequently, the simplistic, superficial and unflattering views and judgements of traditional accounts of the King remain in force.

Contributing to this unfavourable view of Louis XII undoubtedly has been the few available conventional sources for the reign compared to that of the King's predecessors and successors. And, ironically, the resulting ignorance has only compounded the traditional disdain for Louis XII's reputation. Despite knowing little of his reign, nineteenth- and twentiethcentury scholars have not been prevented from jumping to decisive conclusions, based upon limited information, that have unjustly ignored the reputation as "Pere du Peuple" enjoyed by the King during his own lifetime, and remembered by subsequent generations of Renaissance and Early Modern French subjects. 


\section{6 / Renaissance and Reformation}

Both these problems can be corrected by using a particular kind of source-contemporary and near-contemporary accounts of Louis XIIin an effort to reevaluate the King, his role and his significance. The best way to begin such a reevaluation is to focus on the concept of "Père du Peuple" contained in these sources. These accounts are a unique kind of source that should not be dismissed as mere panegyrics. Because they form a substantial reservoir of source material dealing with contemporary evaluations and views of Louis XII, they are not only legitimate in themselves (especially in the absence of a large body of more conventional material), they are also crucial to reopening the study of the reign. They provide both direct contact with the court and contemporary imagery of the King through the eyes of their authors.

Modern scholars may enjoy the advantages hindsight brings them in reviewing a broad expanse of time, but their lack of direct contact often cripples them in their understanding of, or sensitivity to, a particular period of history. It is this that has caused the damage to Louis XII. Scholars further removed from the reign are so distant in time and culture that they frequently do not understand it, while contemporaries-who admittedly lacked hindsight-lived under Louis' rule and so were in a better position to judge him.

The image of a reign and the style of royal government, seen through contemporary eyes, are crucial to the historian's craft in that they give a monarchical age its importance. And they are often defined by the qualities of the monarch. Moreover, these individual qualities are vital for an appreciation of the monarch himself: they are culled from his own character, and influence his methods of government as he strives to uphold standards he or his admirers have set. At least one of Louis XII's contemporaries, Nicolo di Machiavelli, recognized this important balance between precept and practice, frequently using Louis as an example. He fully appreciated the role it played in sustaining the popular image of the king of France. Dubbed "Père du Peuple" by his adoring subjects, Louis always strove to live up to his reputation through good government and paternal rule, on which his sobriquet was founded. His subjects saw in their monarch a man of noble character committed to their best interests. Indeed, their accounts of the King seem to emphasize the traditional image of a "good" prince, comparing in particular Louis' almost sacred relationship with his subjects with that between a father and his children.

Machiavelli also defended the need for a prince to act contrary to that good image in order to maintain the state. Although such actions might in the short term earn the prince some criticism, in the long run-if they bring success-they ironically increase his subjects' appreciation of him as a good ruler. The prince is seen thereafter as a great man who seeks nothing but the good of the state: "The ends justify the means." Louis XII was an 
excellent example of this. He had to rise above numerous problems to uphold his sobriquet as "Père du Peuple"; he had to overcome criticism for his parsimony, the scandal of his divorce from his first wife, and the hostility of the Breton nobles and Parisians to his second marriage-just to name three. Despite these conflicts, Louis' image-which was in fact strengthened by the difficulties - not only emerged intact but also survived throughout the Ancien Régime as the hallmark of his reign. This shows that Louis' image as "Père du Peuple" was founded upon something more enduring than the exaggerated praise of his panegyrists, and that he was far from being a plaster saint.

Why was Louis XII so highly praised by his contemporaries and nearcontemporaries? How was it that he earned the sobriquet "Père du Peuple" in his own lifetime? Surely, we must agree with Roederer's criticism of those scholars who have suggested that one needs only to be a mediocrity to be called "Père du Peuple." Louis, then, must have represented something to his people that has escaped us. If they could not evaluate the King by hindsight, they surely could see the setting in which he ruled. Contemporaries had to place him within the context of a state still recovering from the Hundred Years War, and a monarchy consolidating its authority at the unfortunate expense of high taxation and heavy-handed royal law, if not justice. Furthermore, they could remember the new king's former role as duc d'Orléans, cousin to King Charles VIII, and leader of elements within the state who had opposed Charles' unpopular methods. In general what they saw was the continuity of post-war consolidation and recovery, coupled with royalist reform directed at the perceived abuses of the previous reign. Particularly, they praised Louis XII for undertaking major reforms in justice, finance, the university, the Gallican church and the army. Throughout, they sav the kingdom prosper from these reforms and grow ever wealthier, stronger and happier.

Who were these contemporary and near-contemporary evaluators of the reign, and what was their relationship to the court? For our purposes here, they can be divided conveniently into three groups: the generation that enjoyed Louis XII's personal reign; succeeding generations who served the last of the Valois kings; and a handful of sources drawn from later periods used to show continuing attitudes toward the King. Of Louis' contemporaries, undoubtedly Claude de Seyssel (1450-1520) is the most important source. He served as a royal councilor, as an ambassador and as the bishop both of Marseille and Turin. He was the most enthusiastic supporter of a royal master whom he adored. Other individuals who were present at court or who served the King faithfully include Louise de Savoie (1476-1531), the mother of the future François Ier, Father Humbert Vellay (d. circa. 1520) the King's confessor, the seigneur de Fleurange (1491?-1537?), a childhood companion of François who married into the 


\section{8 / Renaissance and Reformation}

family of cardinal Georges d'Amboise and who served the King in Italy from 1509 to 1516, and Jean d'Auton(1466/7-1528), a protégé of Queen Anne who accompanied her husband on the initial campaigns in Italy. The perceptive Philippe de Commynes (1447-1511) serves as a useful source for Louis as a young man, as does Jean Molinet (1435?-1507), who was active in the governments of both Charles VIII and Louis XII until his death. The memoirs of Jean Aubrion (1441-1501) are equally important, and were continued after his death by his cousin Pierre until 1512.

Other contemporary sources include Saint-Gelais' history of the reign, probably completed c. 1514, Jean Bouchet (1476-1557), who was attached to the powerful La Trémouille family, and "Le Loyal Serviteur," who appears to have been secretary to the chevalier de Bayard and a witness to his activities from 1500-1524. Alain Bouchard (d. 1531), Nicole Gilles and Martin du Bellay (whose memoirs begin in 1513) are useful sources as well, though information on these authors is scanty. There were also two poets whose work serves as a further source: Jean Lemaire de Belges (1473?-1525), a Flemish poet and historiographer who served Marguerite d'Autriche though he wrote in France, and Jean Molinet (1435?-1507) who wrote commemorative poetry for Louis XII. The two most useful and reliable foreign sources for the reign are Francesco Guicciardini (1483-1540) and Nicolo di Machiavelli (14691527), who enjoyed first-hand knowledge of Louis XII. Their perceptive treatments of the period were largely unaffected by diplomatic expediencies.

Of the near-contemporary sources of the reign, the most important include Pierre de Brantome (1540-1614), whose family had a long attachment to the Valois court, Jean Du Tillet, a contemporary of François Ier who had access to the court as well as to the royal archives, and Étienne Pasquier (1529-1615), a lawyer and man of letters who faithfully served the later Valois kings. In addition, the histories written by François de Belleforest (1530-1583), historiographer to Charles IX, Nicolas Vignier, who appears to have been historiographer to Henri III, and Jean de Serres (1540-1598), a pro-Bourbon Protestant minister, include detailed and accurate accounts of Louis XII and his reign.

Finally, the histories written by the seigneur du Haillon (published 1516-16), the sieur de Mézeray (1688), Father Daniel (1725) and D. Michel Felibian (1725) belong to later periods. These authors drew heavily upon earlier sources and reveal the continuing attitudes toward Louis XII which reaffirmed his reign as something of a golden age.

Although much of their evaluation of the King was positive, these men were not indiscriminant sycophants. First and foremost, they saw Louis as a man of flesh and blood with a personality of his own. And, as a man, he was as fallible as any of his subjects. If contemporaries saw his strengths in 
the paternal and conscientious rule that earned him his title "Père du Peuple," they most assuredly saw his weaknesses in military affairs and in decisions concerning foreign policy. ${ }^{4}$ To them, Louis was a multi-faceted human being composed of strong character traits and not the rather obscure figure implied by the shortage of modern investigation.

"It is true that so great a prince also had several vices," commented Bernard de Girard in 1614. In his youth, Louis had had an "inconsistent and sensual" spirit and he was something of a libertine. ${ }^{5}$ Philippe de Commynes agreed, complaining on one occasion that Louis "loved his pleasure," a characteristic that even the sobering influence of Queen Anne, his second wife, was never able to suppress completely. ${ }^{6}$ And the numerous successes and victories won during the reign gave the King enough excuse for holding balls, tournaments and banquets. This love of ostentation extended also into his love for expensive clothing. Claude de Seyssel commented on one occasion that the king

... is more pompous in clothing and personal accoutrements, than was King Louis XI ... that too often he dressed more like a merchant, or a man of base condition than a king, which is not very fitting for a great prince. ${ }^{7}$

Louis XII also projected an athletic image, although he did not enjoy a robust constitution. He was an enthusiastic hunter and, according to SaintGelais, this was as much his pastime as king as it had been part of his early education. ${ }^{8}$ Hunting bad accustomed Louis to handling horses well and, by the time he was sixteen or seventeen years old, he was an accomplished horseman. According to contemporary reports, the King seems to have taken every opportunity to hunt, sometimes for weeks at a time. Jean d'Auton reported both that the King often spent autumn at Blois to pursue his pastime and that it agreed with the King. Louis "always found himself growing plump ... and it completely revished the queen with joy to see the king prosper in state and returned to health."' The love of the chase never left him; indeed, his hunting establishment was an extensive one, including both falcons and hounds. ${ }^{10}$ Louis was active in other ways as well. He was talented in jumping on horseback, wrestling, tennis, archery and in the use of arms.

These material instincts of Louis XII's character formed a necessary contrast to his more positive qualities, in that contemporaries were concerned that the King would follow the wayward pattern of his youth. However, what they saw, and admired, from the moment of Louis' succession, was his serious pursuit of his royal duty. Where he might have indulged only in the pleasures of kingship and in none of its responsibilities, individuals-like Saint-Gelais-noted that the King instead abandoned these instincts in the firm conviction that "the sovereign prince must be the 
light of the others." "And from this conviction followed his other noble qualities. Thus, Louis XII himself provided-at least in contemporary eyes-the firm foundation of his future image as "Père du Peuple."

The King's positive traits of personal honour and military valour were among those which contemporaries believed grew from this spirit. These characteristics not only reinforced Louis' image but also formed the principal pillars of support for it. Like most men of rank and position who stood as an example to others, Louis XII pursued personal honour with an eagerness that his contemporaries noted with admiration. Often this meant overcoming personal infirmities. He continued to lead his army in the field against Venice in 1509 even after a horse had fallen on him, seriously injuring his leg. Saint-Gelais remarked that there were those "who would stop for less. But he has a vigour of the heart, when it is a question of honour, which drives him, and makes him forget all his ills." In 1503, Archduke Philip of Austria was treated well by Louis regardless of the transgressions and diplomatic treachery of his father-in-law, Ferdinand of Aragon. The King had refused to detain the humiliated duke, allowing him to return to the Netherlands instead:

Because if Philip's father-in-law had been faithless, Louis did not want to resemble him, as he preferred to have lost a kingdom, which could quickly be retaken, than his honour which he never could recover. ${ }^{12}$

But pursuit of personal honour was only one side of the coin in an age when kings were supposed to excel as soldiers as well as civil administrators and judges. Contemporaries noted that Louis XII-like many of his fellow monarchs-was an enthusiastic soldier who "had in him a natural virtue and vigour which astounded many men ...."13 The King was admired for his willingness to share in the hardships of a campaign with his soldiers and to expose himself to enemy fire. Once replying to his officers' entreaties to stay out of harm's way, Louis said "I have no fear at all of the enemy artillery; and whosoever is afraid, let him hide himself behind me, and he will not be harmed." 14

An equally strongly perceived trait was Louis' penchant for candour and honesty in personal relations, which greatly added to his image as "Père du Peuple." He detested gossip and false flattery, and, whenever someone was criticized unfairly, the King demanded proofs of his indiscretion. When he heard excessive praise of himself, Louis grew impatient and quickly changed the topic of conversation, saying "I like it best when praise is [found] in the hearts of men [rather] than in their language." ${ }^{15}$ Bouchet remarked that the King distrusted criticism of others until the critic's worth had been proven in the royal service. Comparably, those who refused to listen to gossip always occupied "an honourable place in his memory." 
Then again, Girard suggested that the King was by nature suspicious; thus, what appears to have been accepted by most contemporaries as Louis' candour may well have been simply his caution and distrust of the royal servants. ${ }^{17}$

Contemporaries maintained that Louis XII loved free speech and could accept criticism from others with appreciation, especially where his government and the court were concerned. He even encouraged the students at the University of Paris to lampoon the court:

I want them to play freely, and that the young men make known the abuses that the courtiers commit at my court: Since the confessors, and others who are supposed to be the wise ones, want to say nothing of these: providing that the students do not speak of my wife, as I wish that the honour of the ladies be preserved. ${ }^{18}$

On another occasion, Parisian comedians significantly caricatured Louis as sick, pale, with his head wrapped in bandages, his cheeks hanging down to his feet, "and holding in his hand liquid gold, such that they sometimes mix among precious medicines, to quench his thirst." "So great was freedom then in France," that instead of punishing the players, the King laughed at his caricature and loudly praised the freedom of his people. ${ }^{19}$

In addition, the King liked books and cherished men of learning even more. Himself the recipient of an excellent education in his youth, he eagerly advanced scholars who showed real merit, "but most often those who were capable of instructing and serving than those who only flattered and pleased him." ${ }^{\prime 20}$ Louis initially favoured the University of Paris, granting its members honours, benefices, increased wages and pensions, and attracted great scholars from Italy. ${ }^{21}$ By this means, the Latin of French clerks (which was "rude and barbarous") was improved, and spoken Latin became more common than before. Later, as duke of Milan and Pavia, Louis improved the universities of these two cities, hired scholars, and made of them widely recognized centers of learning. ${ }^{22}$ It appears he even appreciated the freedom of the press (though still limited), particularly shown by his confirmation of the rights and privileges of the Parisian publishing houses later in the reign, ${ }^{23}$ as well as the addition of printed books to the royal library. This paternal interest in education on the part of the King only confirmed contemporaries in their belief that Louis had earned the sobriquet "Père du Peuple," a title "to which he was very sensitive and was only concerned with supporting with honour."24

From these positive aspects of the King's character developed the paternal reputation of Louis XII's reign: contemporary observers believed they motivated his sincere desire to rule with justice and with honour. Louis was regarded by his subjects as a father who sought to protect and 


\section{2 / Renaissance and Reformation}

benefit his children, punishing them only when absolutely necessary. In defining this close and almost sacred relationship, contemporaries emphasized the decisive role of Louis' personality in his belief that the law must govern even kings, his recognition of the authority of duly constituted assemblies (e.g., the parlement), his appreciation of the monarch's responsibility to unburden his people financially, and his perception of the monarch's sacred duty to protect the small and weak from the great and powerful. It is not surprising, therefore, that Louis' reign was considered fortunate and prosperous by the same contemporaries. Consequently, when later generations looked back to the record of his reign across an extended period of internal and external upheaval, the tranquility, stability and prestige of Louis XII's France were hailed as a kind of golden age when the "Père du Peuple" ruled with "just and gentle hands." 25

It was implied by his contemporaries that Louis' style of rule and his choice of royal servants, ministers and officers followed naturally the dictates of his personality. When Charles VIII died, Commynes remarked that he had ruled not through royal authority but through royal favourites, who frequently bent the royal will to suit their own purposes. Girard added that the same could be said of Louis XII with this exception: Louis ruled both according to his authority and through his ministers, but the latter were men of virtue who obeyed their king. ${ }^{26}$ Moreover, toward government officers, the King was not "terrible, rigourous, austere, difficult or variable, but always constant, humane, gentle and familiar." He dealt with them in private "not like a king but like a companion." 27

At the beginning of the reign, Louis was under pressure to purge the late king's household of his old adversaries by men motivated chiefly by jealousy, vindictiveness and greed. Louis, duc de La Trémouille, who had captured and imprisoned the young duc d'Orleans for Charles VIII during "La Guerre Folle," was especially singled out as a prime target for revenge. Despite past antagonisms, Louis was willing to begin afresh and so refused to listen to the Duke's enemies. Contemporaries admiringly reported the King's reply to these sycophants,

... that it was unseemly for the King of France to avenge injuries made against the duc d'Orléans, and that if [La Tremouille] had served the [late] King against him, he would do the same for [Louis] as king. ${ }^{28}$

Therefore, Louis XII "confirmed [the duke] in all of his estates, offices, pensions and benefits" in return for La Trémouille's promises of loyalty and obedience. ${ }^{29}$

There were others at the court who were well aware of the designs of the favourites of the new king, especially among the late king's servants who feared the succession of the duc d'Orléans to the throne. They complained 
"that according to the ancient rules of the realm, Louis was ineligible to the dignity of the crown since he had taken arms against it in the wars of Brittany" of the mid-1480s ${ }^{30}$ These men had opposed the duc d'Orleans and now feared that at his succession to the throne they would be deprived of their honours and privileges and would be punished for their earlier opposition. They were especially frightened when the new king had a list compiled of the royal officers of the last reign with a cross marked beside the name of each who had stood against him. Louis attempted to calm their fears, explaining that "the cross was the mark of Christianity; it signified that he pardoned as a Christian his [former] enemies". ${ }^{31}$ But because they were still unconvinced of his good intentions, as soon as Louis had observed a period of mourning for his late cousin, he gathered together the great nobles of the court "and maintained them all in their dignities and in their quality." 32 Thus, commented Commynes,
.. L Louis wisely entered into possession of the kingdom, as he reduced none of the pensions, for this year, which still has six months to go. He dismissed few officers, and said that he wanted to keep all men in their possessions and estate. ... ${ }^{33}$

In a word, Louis XII was careful not to antagonize anyone at the outset of his reign. His succession thereafter was met with general approval. ${ }^{34}$

If the King could be generous to his old enemies, contemporaries attributed this both to his excellent character and to the lessons he had learned in his youth. Certainly, it was believed that his long imprisonment after the battle of Saint-Aubin had taught him to be merciful and wise:

He was a good King, because he had been a subject for a long time, and he had
learned to moderate the rigours of sovereign commandments, because he had
resented them [in his youth]. ${ }^{35}$

Louis, too, had experienced the bitter taste of royal reprimand and had learned as a result to temper his rule with justice and mercy.

Where it was a question of royal rewards for services obediently rendered, Louis' generosity towards his officers was regarded by contemporaries with mixed feelings. Some, like Father Vellay, considered the King's liberality to be one of his greatest assets, ${ }^{36}$ while others insisted that Louis, in fact, gave very little even to his most devoted servants-he always feared over-burdening his subjects. ${ }^{37}$ Consequently, although the King was followed eagerly by his nobility on campaign, ${ }^{36}$ this does not seem to have been inspired at all by his royal largesse. There were those who were dissatisfied with Louis' apparent stinginess, particularly the officers who had conquered Milan in 1500. These men complained that the King had scarcely provided any reward for them. But Louis always re- 
warded according to merit when he gave anything at all. ${ }^{39}$ And, moreover, Queen Anne frequently came to Louis' rescue, providing them with the honours and pensions that her husband was reluctant to grant. Some of the rewards granted by Louis tended to be privileges that cost him nothing, as in the case of the seigneur de Fleurange who was permitted to lead 200 horse in the field rather than the customary 100 men per nobleman.

Louis' critics to the contrary, d'Auton argued that the King was always cognizant of the service of his men and conscious of their good deeds, "so much so that, under his hand, [they were] highly remunerated and widely recompensed: to his loyal servants [he] gave high offices and good wages...."40 And, according to Seyssel, Louis rewarded all equally to avoid creating general discontent by enriching only a few as Louis XI had done. ${ }^{41}$ It also appears that Louis was highly selective when granting rewards. Indeed, "the King, who did not much like fortune hunters, gave his favour entirely to those who handled weapons, [and] began to invite [these soldiers] to his court, [offering] pensions and rewards." 42 Consequently, if Fleurange is an example of the limited nature of the King's gift-giving, then the duc de La Tremouille is an example of his generosity. With the victory of Novara (1500), Louis promised that "if I do not die too soon, I shall reward him in a way that the other captains will have the desire to serve well." 43 True to his promise, La Tremouille was granted the government of Burgundy and created admiral both of Brittany and Guyenne.

For some contemporaries, the King's parsimony was seen as a virtue that may well have contributed to the positive image of his paternal rule. Machiavelli suggested that the King's "long stinginess" alone permitted him to pursue the wars in Italy "without laying an excessive tax on his people." 44 Étienne Pasquier, although a full generation removed from the reign, specifically pointed to Louis XII as an example of a king who wisely subjected the pecuniary interests of his court nobility to his responsibilities toward the protection of his people. He wrote that the King did not grant lavish rewards to his servants, thus earning the reputation from them "for being more restrained in his gifts. . .." For this reason alone he deserved to be called "Père du Peuple," because he chose to observe his duty as king toward the common subject. ${ }^{45}$

Unhappily, there is very little indication of the common subject's opinion of the King, and what exists is scattered and incomplete. Throughout his reign, however, Louis seems to have been especially concerned for the just treatment of the menu peuple. Indeed, Saint-Gelais remarked that if he "was gracious as duc [d'Orléans], he is much or even more so as king, as there is none who can surpass him in graciousness and gentleness toward the humble...."46 Saint-Gelais further recorded that, in 1504, when Louis fell seriously ill for the first time, the common people lamented 
throughout the kingdom "for the grief that each person felt for his good king's illness." Men and women went day and night to the churches to appeal to the Almighty for the restoration of Louis' good health, a monarch "whom they had so greatly feared to lose, as if he were the father of each."47 D'Auton reported a similar reaction, writing that the common people left their labours in order to flock to the churches in droves, "their hands clasped and their eyes held on high" to pray for the King. In addition, he included a prayer (which he attributed to the common people) which was spoken for the sick monarch. It ended, "listen to the piteous cries of Thy poor people, Lord God, ... to this propitious request, in giving prompt health and long life to our very Christian King." 48

The only other indication of popular attitude to Louis XII concerned the King's procession through Champagne and Burgundy in 1510 . He was very well received by his people, who ran after him trying to touch "his mule, or his robes, or something else of his." If they succeeded in doing so, they kissed their hands, rubbed their faces and displayed "as much devotion as they showed to any reliquary." One gentleman in the retinue, seeing an old man running after the King, stopped him to say that if he continued at such a pace he might do himself an injury. The old man replied that he was hurrying to see the King, whom he loved and honoured, because of the care he had shown for his subjects. ${ }^{49}$ The old man added that the King "maintains justice, and lets us live in peace and removes the looting of the soldiers, and governs better than ever a king did":

And through this one can consider that it is the great hour of our prince that, through his good deeds, he collected the hearts of those who in the past have been such enemies of his predecessors. ${ }^{50}$

In terms of state policy, one of the most important and immediate issues was Louis' second marriage. And it was an issue that received particular attention both from the King's detractors, who accused Louis of shameful behaviour, and his apologists, who either had to justify the King or explain away the "scandal." Essentially, the King wanted to divorce his first wife, Jeanne de France, in order to marry Charles VIII's widow, Anne de Bretaigne, and thereby maintain the duchy of Brittany within the French realm. ${ }^{11}$ To do so, Louis found four "legitimate" reasons for an annulment. First, he argued, he had been forced in 1476, as duc d'Orléans, to marry Jeanne "by express orders of her father," Louis XI, who threatened his life if he refused to comply. Second, Jeanne was generally held to be if not barren, then physically incapable of consummating the marriage because of her bodily deformities. Ironically, it was on the basis of the assumption that the Orléanist line would die out as a result of this that Louis XI had insisted on the marriage of his daughter to the future Louis XII. It was widely 
suspected that the old king did this to ensure the crown to his own immediate successors. Third, Louis XII's ministers argued that, as the King and his wife were separated by only four degrees of consanguinity, the marriage was invalid. Finally, Louis repeatedly swore that the marriage had never been consummated. In fact, when ordered by Louis XI to lie with Jeanne, he had placed secret witnesses in the room to prove that the act was never committed. ${ }^{52}$

According to Louis' apologists, the King was "pressed by the princes of France, the Parlement of Paris, churchmen and others to divorce his wife for reasons of state. Jeanne's alleged sterility was declared by Jacques de la Guelle, procureur général du Roy, to be the deciding factor because political necessity and state security-which were seen at the root of what the courts held to be a positive decision essential for the protection of France-demanded a direct line of succession. ${ }^{53}$ Thus, Louis sacrificed personal interests for the good of his people "by whom, through a rare and singular epithet, he was called father. ..." 54 But Louis' critics condemned the affair as a complete disgrace. One author even refused to write about it for fear of condemning "the historians who described it to the prejudice of the good lady, and to the advantage of King Louis XII. . . ."55 Despite their agreement that Louis had been forced into the marriage by fear, this did not protect him from criticisms that he had neither loved nor served his wife "as he should have," while the saintly Jeanne had accepted her disgrace "with great patience and a genuinely Christian constancy. ..." In In addition to Louis' interest in Brittany, these critics suggested that the King sought the divorce simply because Jeanne's physical deformities "made her very disagreeable" to look at, ${ }^{57}$ and he was "hostile to the memory of her dead father and brother. . . ."58 Some also claimed that the King, as duc d'Orléans, had been in love with Anne de Bretaigne, had sought her hand before her marriage to Charles VIII, and again at his own succession. ${ }^{59}$ Even Brantôme was convinced that Louis XII had divorced his first wife for love of his second.$^{60}$ Guicciardini denied this, however, writing that the affection Louis had once felt for Anne was gone and that he was far more interested in her duchy than in her attentions.

The King attracted still more criticism for the questionable honesty of the divorce proceedings. He was accused of being in collusion with Alexander VI, who sought the King's aid in advancing his bastard son, Cesare Borgia, into the secular world. Louis' ambassador to Rome, they said, "missed no opportunity to join artifice to reason to aid in the designs of his master. . . ""61 Meanwhile, Jeanne-who struggled to maintain her position as Louis' legitimate wife, declaring that the marriage had, in fact, been consummated $^{62}$ - was aided by only one lawyer, Maitre Jean de Vesse (or Besse) of Brouges. By contrast, the King enjoyed the support of the court, the parlement and the church. ${ }^{63}$ In the face of such overwhelming odds, 
Jeanne finally admitted defeat, the marriage was annulled, and, on 8 January 1499, Louis XII and Anne de Bretaigne were married.

Not everyone favoured the new marriage, least of all the Breton nobility and the citizens of Paris. The former feared they would lose their own laws and customs under their new king. They quickly approached Louis to ask for royal guarantees that would safeguard their privileges and, in a lengthy treaty with the Breton Estates, Louis agreed to do so. ${ }^{64}$ What this amounted to was almost complete autonomy for Brittany, which created still more criticism of the King, who was accused of throwing away the advantages his second marriage was supposed to secure. The Parisianswho had been the only ones to benefit from Louis XI's reign-grumbled loudly over Louis XII's repudiation of the old king's daughter. On the pronunciation of the divorce, it was reported that a great storm suddenly blew up which so darkened the sky at noon that torches had to be lit, an indication that a "great wrong" had been committed against Jeanne and a sign of God's discontent. The people called the judges and churchmen involved in the proceedings "Herod" and "Pilot" in the streets, while Père Maillard continued to preach publicly that Jeanne was the King's "true and legitimate wife." ${ }^{65}$ In fact, the murmuring over the "scandal" was serious enough to receive strong support from various faculty members of the university, of whom several doctors of theology at the Sorbonne were exiled from Paris, though they were later recalled. ${ }^{66}$ This seems to have been a problem between the King and the Parisians that was never fully resolved, and possibly explains Louis' preference to live at Blois rather than in his capital, as well as his later restrictions on the privileges of the university.

It was in matters of state-particularly in his reforms-that Louis received his highest praise. Continuing the policy of consolidation of the French monarchy begun by his predecessors, the King attempted to redress and correct major abuses in the judiciary, finance, the university, the church and the army. In all five areas, royal pressure brought the reforms to a successful conclusion and earned the King the praise of his subjects through his sobriquet as "Père du Peuple."

Contemporaries suggested that the King's major focus in reform was directed toward the administration of justice. According to them, Louis recognized that combined with his authority "to make and create laws" was his duty to reform pernicious or dangerous abuses. ${ }^{67}$ Beginning at the peak of the judicial hierarchy, Louis redefined the status of the parlements, added judges and prohibited venality of judicial office. He weeded out incompetents from the judiciary, forcing everyone from the judges to the clerks to write an examination administered by the chancellor and to submit to an intimate examination into private life and morality. Louis also turned his attention to reforms in the provincial parlements, especially in 


\section{8 / Renaissance and Reformation}

Normandy and Provence. He ended abuses committed by the officials there, placing all activities under royal supervision. Finally, he reduced the expenses involved in legal actions and sought to limit the duration of cases before the courts. In a word, Louis streamlined and improved the administration of justice throughout the kingdom, reducing the parlements to their original, legal status in order to separate them from involvement in decisions of state. ${ }^{68}$

The King's contemporaries widely praised him for these reforms. They agreed that he "wanted all crimes to be punished by the ordinary judges, in following the order of the law and reason, without deciding anything by caprice." 69 Through his zeal, hard work and the interest "he had for the public welfare," an equitable judicial system was established. It had been improved "so much that the lowest [peasant] enjoys justice against the greatest [nobleman], without any favouritism: if the King was told that there were any of his judges favourable to one of the parties, he punished the offender in order to make him an example to the others." "70 Saint-Gelais added that Louis was obliged to do so as part of his duty toward his subjects "due to his royal dignity, which is justice. ..." "71

Even more striking, contemporaries did note the King's respect for the law. He left his magistrates great freedom of action and never tried for his own purposes to influence their decisions in the belief that "it was of little worth to have made good laws and ordinances without establishing judges having the authority to protect and execute them." 72 These contemporaries attributed both to Louis' desire to rule always through justice and to his character.$^{73}$ Comparably, Louis published an edict in which he commanded that no royal ordinance be issued to the public as law without first being ratified by the parlement.$^{74}$ By so doing, the King established the tenure of the royal judges, enhancing their role, which won Louis the sobriquet "Père du Peuple" within the judicial community. This edict was proclaimed by the courts time and again throughout the Ancien Régime whenever the judges feared the erosion of their powers by royal authority. (Hence the widespread praise of Louis XII's memory during the Fronde.)

Among the legacies left the French people after the Hundred Years War and Charles VIII's Italian venture of 1494-5 was heavy taxation. This was a burden that certainly added to the unpopularity of Charles, his father and his grandfather, and perhaps also to the rebellions- popular and noblethat erupted from time to time, disturbing internal peace and stability. Louis XII was well aware of the problems created by high taxation and sought to unburden his people of this heavy weight. He reduced the yearly tailles to a tolerable level and remitted the "free gift"- a large sum of money traditionally given to a new king to defray the expenses of his coronation and his predecessor's funeral. He charged nothing to the kingdom for his own household, and he repaid the debts of Charles VIII, 
despite the weak condition of the royal treasury. Finally, he reformed the French currency which had in past reigns become badly debased. ${ }^{75}$

Louis was widely praised for his efforts in this regard. Saint-Gelais wrote of the King that "in Paris, Rouen, Tours, there is no merchant who more faithfully pays his debts than [Louis] does his," adding later that when Louis needed money for the assault on Milan (1499) "he went nowhere else to look to finance it than in his own coffers, which it did not bother him at all to empty."" By setting this example, many "good subjects" freely contributed money to help pay for the military expenses. Mézeray later commented that the King "knew that the spending of the Prince is like the spleen, the smaller it is the better is the condition of the state." 77

A second source of income for French monarchs had been venality of office, a practice that Louis XII followed initially, simply because of his need for cash to pay for his army in Italy. ${ }^{78}$ Although venality had been rampant in France during previous reigns, some, like Nicole Gilles, claimed that the new king had been the first to institute it. ${ }^{79}$ Pasquier later commented in favour of Louis that, "as he was above all else devoted to unburdening his poor people, he esteemed that he could best unburden them by placing a taille on the ambition of the wealthiest, in buying offices." ${ }^{80}$ The King soon recognized the problems created by venality and stopped it altogether, declaring rights and privileges thus acquired to be invalid. ${ }^{81}$ Louis' accomplishments in financial reform were so successful that in 1499 " all the people praised him wonderfully [for it], and [he] won the hearts of many others." ${ }^{82} \mathrm{He}$ was always afraid of "burdening his people too much, which was the one thing in this world which gave him the greatest regret. ..." France was at war with the Pope, the English, the Empire, the Swiss and the Spaniards, Louis refused to create additional taxes or to curtail the salaries of either his officers or his judges. ${ }^{84}$

Claude de Seyssel surveyed France's strong financial condition during the reign with enthusiastic approval. He wrote that the King had purified the money supply, which had become debased during the preceding reigns, and had punished counterfeiters. Revenues received from benefices and estates were plentiful and those generated by various taxes-the gabelle, péages, grêffes, aides - had increased due to the rising prosperity of the kingdom. Commerce also had increased significantly, as had the numbers of merchants thus engaged. Because conditions of travel by land and sea had become safer, shipping costs were reduced and the collection of royal revenues had become more efficient. Seyssel even argued that the standard of living had risen substantially, shown in the increase in building large, richly decorated private and public edifices; the widespread use of gold and silver plate by aristocrats, clergymen and merchants; and the growing 
expenses of dowries, weddings and inheritances. This may also suggest the tremendous influence of Italian tastes and culture on wealthy Frenchmen from Louis' campaigns in Italy, so often attributed to the reign of François Ier. All things considered, Seyssel claimed that, during the reign of Louis XII and under his guiding hand, France was wealthier than at any other time in her history. ${ }^{85}$

Of all Louis XII's reforms, those in justice and finance were the two most highly praised and reflected best his paternal rule. Contemporaries acknowledged that, since the first day he came to the throne, the King "worked incessantly for the praise of his people, lifting from them the burden of taxes, and taking care to distribute justice to them fairly." ${ }^{86}$ From his careful attention to these two areas alone Louis earned his sobriquet as "Père du Peuple" and the praise of his subjects.

However, the royal reforms extended into other areas too. The King found it necessary to reinterpret the ancient rights and privileges enjoyed by the University of Paris, which had been abused at the expense of the people and royal authority. In this, Louis may have been motivated not only by his irritation over liberties that the university claimed but had no legal right to, but also by the resistance of the university to his divorce. Staff and students alike were annoyed with royal interference and attempted to revolt. But Louis' will, once enforced, proved irresistible, and the royal reforms were pushed through the parlement. ${ }^{87}$

Even the Gallican church did not escape the King's programme of reform. He preserved its liberties and privileges, but set his first minister, cardinal Georges d'Amboise, to clean up abuses in tithing. Essentially, this amounted to the abolition of "certain false impositions which had been levied for 100 years without any edicts of the king." What is more, Louis insisted that his people be reimbursed for their excessive payments. This fit neatly within the king's overall plans to reduce the financial burden oppressing his people for so long. ${ }^{88}$

The King also found it necessary to reform the army. During previous reigns, royal troops had roamed the kingdom, pillaging the property of peasants at will and paying for nothing. It was a problem, moreover, that did serious mischief to military discipline. Louis forbade his soldiers from pillaging on pain of severe punishment, and a number of the worst offenders were caught, charged and punished as an example to the rest. The soldiers soon understood that they "dared not take an egg from a peasant without paying for it," while the measures taken renewed and re-established military discipline "which had almost disappeared." The King restricted the troops to their garrisons and provided sufficient provisions and regular pay, which also helped to discourage their forays into the countryside à la picorée. This was seen as a very positive result of Louis' reforms. ${ }^{89}$ 
But at least one contemporary pointed to some negative aspects of the King's reorganization of the army. Machiavelli believed that Louis XII committed a grave error in reducing the numbers of French infantry in favour of Swiss mercenaries. Not only did this discredit French arms, but it made France dependent on foreign soldiers. Consequently the French cavalry became so accustomed to fighting beside the Swiss that it began to believe it could not succeed without them. Moreover, French arms could only continue victorious so long as they faced armies with a similar organization. In short, by disarming his own people, Louis committed an act "which was contrary to every action and every precept of anyone who has been considered prudent and great."90

However, contemporaries were generally enthusiastic over the royal programme of reform, and they were lavish in their praise for the king who had been its guiding force. They recognized that Louis

\footnotetext{
... wanted so much to work for the increase of the public weal, that, under his hand, the kingdom of France was then very happy, the nobility peaceful, merchandise plentiful and labour fruitful; what is more, justice was duly administered to all. ${ }^{91}$
}

Even Louis himself recognized the benefits that his reforms had bestowed on the kingdom when he wrote

God has given me more grace than I merit . . . I am wealthier than any king of France has ever been until the present ... and, if there was ever need for it, I can gather on a moment's notice a sum of money such that the telling of it at this moment would appear [to be] untrue..$^{92}$

Perhaps the greatest expression of praise for these reforms in particular and for the King in general is found in Claude de Seyssel's La Grande Monarchie de France. Based on the achievements of Louis' reign, this remarkable book was published in 1519 , probably as a guide for young King François Ier. In it, Seyssel examined the development of the fundamental principles of the old French "constitution," written by a man who saw in the late king a monarch adored by his people and devoted to ruling according to his laws. Using Louis XII as his model, Seyssel outlined a system of government where the king-although absolute-voluntarily relinquished his absolute power in order to rule within the legal boundaries imposed on the royal prerogative by the fundamental laws of the kingdom. In turn, permanent judges, who exercise the law and rely upon the king for support, maintain the customary rights and privileges of the social orders, the monarchy and the kingdom as a whole..$^{93}$ This statement, among all that date from this period, comes closest to an understanding of the changing nature of France from a patrimonial into a national state. 


\section{2 / Renaissance and Reformation}

Seyssel was a deep admirer of Louis XII, and throughout his treatise can be seen the deeds of the King through implication and example. Ever concerned with justice, eager to unburden his people of excessive taxes and the threat from the royal troops, determined to rule according to the law, even to the point of submitting himself to its limitations, Louis offered Seyssel an ideal model for what he believed would be the best form of monarchical government for France. And this he contrasted repeatedly with the methods of Louis' predecessors, especially Charlemagne and Louis XI. Seyssel argued that France was "more fortunate, more peaceful, more wealthy and in greater repose and prosperity" under Louis XII, who used reason and justice to secure his authority, than under Charlemagne, who used only force. The bishop drew a similar contrast to the methods of Louis XI. He claimed his royal master was more loved, cherished and desired by his people than was Louis XI, who was feared and despised. Seyssel even wrote that the reign of the "Père du Peuple" was as different from the reign of the suspicious, cruel and cunning "Spider King" as "the Empire of Domition [was] to that of Trajan."94

Yet, Seyssel was not the only contemporary to admire the government of Louis XII. Machiavelli also found it praise-worthy. He wrote that "the kingdom best organized and governed in our times, is France," where the king was restrained by the same laws that secured the protection of his people. He noted that the parlements were the chief element in the preservation of royal law-especially the Parlement of Paris-which renewed that law each time a powerful noble was prosecuted for misdeeds or a royal decree was rejected for its injustice. And he warned that if ever the par lements began to fail in their duty to the people, either they would have to undergo major changes or the kingdom itself would fall to pieces. Machiavelli concluded with admiration that France was "a kingdom more tempered by the laws than any other kingdom of which we have notice in our times."

While contemporaries widely noted Louis XII's paternal rule-his concern for the welfare of his people, the stability and strength of his kingdom, and an administrative system based upon law and responsibility - they also noted his weakness in affairs beyond French borders. In military ventures and diplomatic affairs-particularly where the Italian peninsula was concerned-the King's shortcomings were revealed and criticized by the same subjects. In general, contemporaries were unable to agree on the reasons for defeats the French suffered periodically throughout the reign. Most agreed that problems caused in supply and reinforcement by corrupt trésoriers were major contributors to the military reverses. ${ }^{96}$ Similarly, French armies were plagued by divisions in command where mutually jealous generals gave priority to their quarrels instead of the campaign at hand. ${ }^{97}$ Although Louis XII recognized these problems 
and quickly took measures to end them, he did not receive any real praise from his contemporaries. In fact, the tone used by them in describing these events suggests that they blamed the King for permitting the conditions in the first place. After all, had it not been the King who appointed these men to positions of responsibility?

Fleurange probably was the most critical of the King where military matters were at stake. Although he praised Louis as a good prince and a devout Catholic, he wrote that "he was not a soldier at all." $98 \mathrm{He}$ was especially vocal about the events of $1512-13$, after the French victory at Ravenna. As the war turned against the French, Louis ordered his new commander, the seigneur de La Palice (who had replaced Gaston de Foix after his death), to divide his remaining forces into garrisons for Frenchheld cities and fortresses in Italy. Fleurange heartily disapproved of this strategy, maintaining that, had the King reinforced his army instead of dividing it, he might have salvaged the initiative and expanded his Italian possessions. Furthermore,

I want to say that this fault has been the cause of all the wars which have since been fought in Italy and in the largest part of Christendom; and, if he had then reinforced his army before, he would have been prince over all Italy, and king of Naples also; as he had the Emperor Maximilian with him, and they fought the largest part of the war together. ${ }^{99}$

As a result of Louis' decision, the French garrisons fell piecemeal, and Pope Julius II, the King's implacable enemy, was able to isolate France diplomatically.

In addition, the King was criticized for his carelessness in preparing fortifications and armies for war. Fleurange again complained that Louis "had not provided for a single fortress" along his Spanish frontier, although he had had money and time enough to do so. Nor did the King entertain at court an expert advisor who could oversee his preparations and suggest improvements. ${ }^{100}$ Fleurange quite plainly saw Louis' naiveté in military affairs as being at the root of many French defeats. Nor was he alone in his criticisms. Mézeray later remarked that "the King neglected to take the necessary measures" to prevent his defeat at the hands of his enemies. ${ }^{101}$ These attitudes were confirmed by those outside the kingdom. For example, Guicciardini added his admonitions, claiming that "the French King was very slow in making these provisions . . . because of his usual negligence. ..."'102

Although widely praising his courage, enthusiasm and conscientiousness on campaign, contemporaries agreed that these qualities alone were insufficient to win wars. Nor did quick remedies for serious problems excuse the man who was ultimately responsible for creating many of those 
same problems in the first place. Perhaps Fleurange's thoughts best expressed contemporary opinion, suggesting that Louis should have allowed the professionals to fight the wars for him.

Nevertheless, as far as Italy was concerned, Louis achieved considerable success. In a lightning campaign in 1499, the French secured both the duchy of Milan - to which the King had direct claim through his grandmother, Valentine Visconti-and the city of Genoa. Except during the Milanese revolt in 1499-1500, followed by a similar revolt in Genoa seven years later, the French maintained their control over the two communes for the majority of the reign. Louis implemented a series of reforms, based upon his work in France, which were the foundation of his rule; and he installed a series of loyal, competent royal governors to administer his new possessions. So successful was the King that Milan and Genoa remained under his rule until 1512-13 - the nadir of the reign-when France was surrounded and assaulted by the other great powers of Western Europe. Much less successful was the combined Franco-Spanish assault on, and division of, the kingdom of Naples in 1501-4. Although the war was a sharp one that ended in success for the the two allies, they soon became divided, leading to a struggle between France and Spain for complete control in Naples. Internal problems in the French army and diplomatic trickery on the part of Ferdinand of Aragon created the conditions for the new struggle- a struggle in which, by 1504, Louis XII had been humiliatingly defeated and the French thrust out of Naples.

In Milan, what had begun as a dispute between the royal tax collectors and the Milanese butchers escalated into a general revolt after the indiscriminate use of force by the royal governor, Jean-Jacques Trivulce, had failed to prevent the spread of violence. Ultimately, the King was blamed for the crisis. Despite Trivulce's ability and his Milanese birth, contemporaries believed that the King had erred in choosing him to be the governor. Trivulce was partisan to the old Guelph faction in Milan; he was fierce, haughty and violent, "qualities very improper for cementing a new authority." ${ }^{103}$ In addition, one historiographer suggested cautiously that Louis should not have left the duchy so soon after its initial seizure:

I will not venture to say that King Louis XII made a blunder in returning so soon to France . . . but the consequences only showed that the absence of the King caused the disorder which erupted in Milan, nor do I want to say in good conscience also that His Majesty had no business leaving. . . ${ }^{104}$

Louis was forced to march again against Milan and to reconquer it. His second conquest of the duchy was followed by measures as benevolent as the first and Trivulce was replaced by a trusted French nobleman, Charles d'Amboise, sieur de Chaumont. 
But where the French king had been successful against Milan, the struggle with Spain over Naples was an utter disaster for France. Contemporaries were quite explicit in casting blame for the debacle on Louis, especially his captains and advisors, for committing the fundamental blunder of agreeing to a joint assault on Naples with Ferdinand of Aragon. By so doing, Louis permitted the Spaniards to establish a firm foothold on the peninsula. These men saw the King's error as "conspiring against his own blood" and found it shocking. ${ }^{105}$ Mézeray later insisted that France was powerful enough to conquer Italy alone, but the King had accepted the bad advice of sharing Naples with the Spanish king on a peninsula where the French were absolute masters already. ${ }^{106}$ Still others blamed the defeat on Louis as "the king had neglected to take the necessary measures" to preserve his authority in Naples, especially in light of Ferdinand's bad faith when, "during this amusement of peace [in 1501-2]" the Spanish monarch reinforced his army and secured his possession of a number of important fortresses. ${ }^{107}$

Machiavelli was just as harsh in his treatment of Louis' activities in Italy and placed the blame for France's failures squarely on the King's shoulders. By permitting the Pope to expand his control in the Romagna by force of arms, Louis not only destroyed the lesser powers who might have been invaluable allies, but also increased the strength of an already powerful papacy. This was to have important consequences later. Furthermore, Machiavelli agreed with other contemporaries that the King should not have joined forces with Ferdinand, that he should have remained in the south much longer than he did, and that he should have taken greater precautions to establish firmly a powerful French presence on the peninsula. Finally, by alienating Venice, he lost the aid of the only state whose friendship might have assured his conquest of all Italy. ${ }^{108}$

Criticism extended to one of Louis' most notable strategic blunders as well. The French galley fleet that had accompanied the army to Naples was ordered to unite with the Knights of Malta in a campaign against the Turks. Although successful, the fleet was destroyed in a terrible storm on the return voyage, effectively eradicating the one weapon that might have been used to prevent the passage of Spanish troops and supplies to the peninsula. French officers had wanted to keep the fleet close to Italy, yet Louis ignored their advice and soon lost an integral part of his defensive force at a single blow. ${ }^{109}$

Finally, one historiographer at least recorded criticism of the King in a policy that in France had been well received but had brought disaster beyond her borders. Girard wrote that Louis "was so stingy and avaricious, that popular opinion has it that, fearing to spend money in vain, he lost the kingdom of Naples...."110 "Until then the French had had the advantage [but] fortune turned almost as suddenly" against Louis as his 


\section{6 / Renaissance and Reformation}

success had been spectacular. ${ }^{111}$ For the above reasons, contemporaries believed that Louis XII had lost Naples to Spain. Harsh as was this criticism of the King, surprisingly little of it was remembered at his death on 1 January 1515. Instead, the paternal nature of his rule was remembered and praised by his subjects and those who surrounded him at court.

When his wife, Anne de Bretaigne, died in January 1514, Louis was badly shaken and from that point his already delicate health began to decline steadily. There is some suggestion that the King ignored his doctors' advice to moderate his activities, ${ }^{112}$ while his third marriage to Princess Mary of England was widely believed to have been a direct cause of the King's last illness. ${ }^{113}$ However, disregarding the many rumours circulating at court-some of them scurrilous-Louis died most probably from dysentery, complicated by his gout, fever and his usual weak constitution.

Reaction to the King's death was, on the whole, sorrowful, with the exception of a number of foreigners who felt relieved by it, as well as those members of his family closest to him. Louis' relation, son-in-law and heir, François de Valois, seems to have been impatient to mount the throne, and this earned him much criticism from the late King's admirers. The previous November, just after Louis' marriage to Princess Mary, François casually remarked to Fleurange on his was to pay his respects to the royal couple,

I am happier and more content than I have been for the past twenty years; as I am sure, or they [his sycophants] are really lying to me, that it is impossible that the King and Queen may have children, which is a fact to my advantage. ${ }^{114}$

When the dying king called François to him for a last interview, Fleurange reported contemptuously that the visit only "comforted [the prince] in his power, and that he did whatever he wanted, but kept up appearances until the King died."115 Louis was not unconscious of the Prince's faults and sadly predicted the wastefulness and luxury of the future François Ier just before he died: "Ah, we have worked in vain, this big boy will spoil everything for us." "116

François' mother, Louise de Savoie, awaited Louis' death almost as eagerly as her son. When the King died on 1 January 1515 , she callously ignored Louis' death, recording in her journal, "[today] my son became king of France." "117 Even the King's new wife, Mary, seems hardly to have been able to wait until her husband died. As soon as a respectable period of mourning had been observed, on 31 March she married the English duke of Suffolk-a young man who had accompanied the princess to France in 1514 and with whom she fell in love. Six days later, she and her husband left France for England with François Ier's blessings, never to return. ${ }^{118}$ 
Louis XII's funeral adhered to ancient French custom. Throughout, he was called "the most Christian and magnanimous Père du Peuple." 119 Contemporaries, in summing up the reign as a whole, widely praised the King for his achievements. The "Loyal Serviteur" wrote, "While alive, he was a good prince, wise and virtuous, who maintained his people in peace, without in any way burdening them, except through constraint." He was praised and loved by his subjects, "and not without cause," as he had kept peace and ruled according to the law. After his death, therefore, "[Louis XII] was called Père du Peuple" and his funeral cortège was accompanied by weeping "and the great regret of his subjects." 120

Louis' confessor, Father Vellay, commented that he was "aided and accompanied by his singular virtue and bounty" and was the greatest prince since St. Louis. He did much for the good and welfare of France for which he was honoured, obeyed, respected and revered by all his subjects." Vellay added that the King always sought to unburden his people, and that his two greatest assets were his liberality and mercy. ${ }^{121}$

Despite his frequent criticism of the King, Fleurange still acknowledged the benevolence of Louis' rule, praising him for his customary kindness, his good deeds and his personal conscientiousness. ${ }^{122}$ Even Guicciardini was able to applaud the late king for his achievements. He called Louis "a just king, greatly loved by his people," although he still criticised him for his inconsistency in decisions made both in peacetime and in war. ${ }^{123}$

Saint-Gelais left a glowing tribute to the King in his biography, especially in the introduction to the work. He wrote that he had decided to record the history of Louis' reign "in order that all other kings and great princes who will follow him, taking example from a virtuous life, in reading ... the virtuous deeds and works that he had begun, conducted and led to their conclusion, as much during times of peace as of war."124 Bouchart wrote that "this very noble King Louis XII, whom one sees prospering in all his affairs, treated his people and his subjects so amiably, that he was conspicuously said to be and called Père du Peuple." 125 Vignier commented that Louis had been a just prince who feared oppressing his subjects "with charges and extraordinary exactions":

This is how he acquired the epithet of Pere du Peuple ... [ [and] to those [ who came] before or after his succession to the crown, fortune was never so constant or stable. . . ${ }^{126}$

Girard echoed these comments later when he wrote that "never were the affairs of the French happier or more powerful, than during his reign." 127 He added that Louis' moderate rule had earned him the name "father of his country."

Father Daniel described Louis XII as "the most accomplished prince of 
his time," in whom nature had joined together a number of excellent qualities. Though in his youth the King had been subject to a number of vices, these had disappeared by degrees until the point where "there are few princes to be met with in history, who have equalled him in royal virtues, or have sat upon the throne with fewer faults." 128

Jean de Serres applauded the reign even more strongly. To him, Louis represented the prince par excellence. He believed that France had never enjoyed such strength and vitality as it had under Louis XII's rule, pointing to the growth of commerce, population, wealth and happiness in the kingdom. Serres claimed that in this the people-who willingly obeyed the king's commands- where "witnessing the excellence and grandure of their sovereign":

In sum, never did a king love his people so much, or a people love their king so much, never had subjects given so much praise to their sovereign than the French to him, [in] the glorious epithet of "Pere du Peuple". ${ }^{129}$

Belleforest agreed with this, adding that the late king had been "the mirror and epitome of a good and virtuous prince." 130 For this reason, he was called "Père du Peuple". Brantome, following the lead of the other historiographers, wrote that Louis was known as "Pere $d u$ Peuple" because he was the "best friend of his people."131

Finally, Mézeray commented favourably on Louis' reign and his excellent attributes. Beneath an engraving of the King included in his history, Mézeray printed a short poem in tribute to the late monarch:

Louis, in whose etching here was drawn the bust

Was the Father of his People, he was good, he was Just

He loved his subjects, he was by them adored,

In their desires his name is still honoured,

As he was sensitive to their ills, insensitive to offense,

He sacrificed all in order to spare France. ${ }^{132}$

That there was, however, some criticism of Louis at his death may be inferred from Claude de Seyssel's answers to the "ingrates and unappreciative people" who blamed the King for the ills of the kingdom. They claimed that, by becoming involved in foreign ventures, Louis invited enemy armies to march against France. They criticised the King for not spending the money necessary to conquer the whole Italian peninsula, although admonishing him for becoming entangled in Italian affairs in the first place. Seyssel answered these charges, writing that this criticism was foolish. Louis' critics would have blamed Charlemagne for the ills of the kingdom, he argued, as a monarch "who made war continually in Italy, Germany Spain and in other foreign lands" and experienced more losses 
and dishonour-especially on the Spanish campaign that ended in the defeat at Ronceval-than ever Louis did in all his wars. Louis had gone on campaign only four times, three months each time, and did not extend his conquests throughout Italy because he refused to raise the taxes. He also was content to take only that which belonged to him and to preserve the liberty of the rest of the peninsula because he feared being labeled a tyrant. Besides, in involving himself in Italian affairs, Louis XII was only claiming what belonged to him as part of his patrimony. Seyssel ended by cautioning the French not to blame the late king for the problems of the kingdom as he had given France "so much glory...so much honour and profit" that it was possible to watch the kingdom grow stronger daily. ${ }^{133}$

Whether or not there was criticism of Louis at the end of his reign, available evidence suggests that he was one of the most popular monarchs ever to rule France. Moreover, he was remembered especially for his paternal rule in which his sense of justice and virtue occupied the key positions. Indeed, Louis' name and reign surfaced from time to time throughout the history of the Ancien Régime as an example to his successors of beneficent rule. In addition, contemporaries and near-contemporaries alike tended to recognize that by the end of the reign France had entered into a new age- an age of vitality and strength in which the kingdom would rise to challenge the traditional powers in Europe. France's growing wealth, internal peace- which had not been enjoyed by a French monarch for a century and a half-and external expansion strengthened her and vastly increased her prestige in the eyes of the western European community. Through her close association with the Italian peninsula, for the first time the Renaissance gained a foothold in the kingdom of France, putting down deep roots into her soil. What Louis had begun and guided in seventeen years of rule, Francois Ier later brought to fruition and enjoyed. It is not surprising, therefore, that Louis XII was hailed even during his own lifetime as the "Father of his people."

\section{University of Southern California}

\section{Notes}

1 I should like to thank Professor A. Lloyd Moote, Professor Richard C. Dales and Professor Paul Knoll for their kind suggestions and the aid offered while this paper was in preparation.

2 P.S. Roederer, Mémoire pour servir à une nouvelle histoire de Louis XII, le père du peuple (Paris: 1819), pp. 7, 363.

3 In fact, of eighteen treatments published since 1969, only seven have dealt with Louis XII directly. These are: Jean-Louis Gazzaniga, "Le conflit de Louis XII et de Jules II devant le Parlement de Toulouse (1510-1512)," Revue Historique de droit français et étranger, 57 (1979), 623-30; François Maillard, "Itineraire de Louis XII, roi de France (1498-1515)," Bulletin philologique et historique du comité des travaux historiques et scientifiques (1979), 171-206; Barbara Hochstetler, "Louis XII, Leonardo and the Burlington House cartoon (six letters, 1507)," Gazette des Beaux-Arts, 86 (1975), 105-9; Jean Jenny, "Sur la date de l'entrée de Louis XII à 
Bourges, 1505 ou 1506," Cahiers archéologie et d'histoire du Berry, 35 (1973), 61-5; Abel Destefanis, Louis XII et Jeanne de France (Avignon: 1975); Mme. H. Hilpert, "Les Trois maris d'Anne de Bretaigne," Annales de la Socièté d'histoire et d'archéologie de l'arrondissement de Saint-Malo (1969), 207-26; and Henri Pernol, "Les marriages d'Anne de Bretaigne," Floréal An. $X, 5$ (1969), 22-30.

4 Foreign opinion and policy will not be discussed here except as they relate to military aspects and as examples of contemporary assessment of Louis' personality and ability.

5 Bernard de Girard, seigneur du Haillon, Histoire Générale des Roys de France (Paris: 1615-16), II, 1304; see also Jean de Saint-Gelais, Histoire de Louis XII, roi de France, père du peuple, et de plusiers choses memorables advenues en France et en Italie, jusques en l'an 1510 . . (Paris: 1622) p. 115; Claude de Seyssel, Histoire singulière du Roy Louis XII de ce nom, père du peuple, facte en paragon des regnes et gestes des autres Roys de France ses predecesseurs, particularisez selon leurs felicitez ou infelicitez... (Paris: 1587) p. 45.

6 Philippe de Commynes, Mémoires sur les regnes de Louis XI et de Charles VIII(1464-98), in F. Michaud et Poujoulat, eds., Nouvelle Collection des mémoires relatifs à l'histoire de France (Paris: 1857), IV, 174.

7 Claude de Seyssel, Supplement aux Mémoires de Messire Philippe de Comines, Seigneur d'Argenton (Brussels: 1713) p. 313. See also, B. Zeller, ed., Louis XII, Anne de Bretaigne, et l'histoire de France, 1498-1515 (Paris: 1889) Part V, p. 166.

8 Saint-Gelais, Histoire de Louis XII. . . , p. 32; Zeller, pt. I, p. 37.

9 Jean d'Auton, Chroniques de Louis XII, R. de Maulde La Clavière, ed. (Paris: 1895) IV, 31-2. Periodically, though, hunting proved dangerous to the King's delicate health, as it did in August 1500. While chasing a large deer, Louis fell off his horse, dislocating his shoulder. For those of robust health, the problem would have been a relatively minor one-for Louis, it was aggravated shortly afterwards by a bad fever.

10 Robert de La Mark, seigneur de Fleurange, Histoire des choses memorables advenues des regnes de Louis XII et de François Ier (1499-1521), in Michaud et Poujoulat (Paris: 1857), V, 9.

11 Saint-Gelais, Histoire de Louis XII . . . , pp. 32, 115.

12 Quoted, sieur de Mézeray, Abrégé chronologique de l'Histoire de France (Amsterdam: 1688), IV, 432; Saint-Gelais, Histoire de Louis XII. . . , p. 164.

13 Saint-Gelais, Zeller, pt. III, p. 98.

14 Pierre de Bourdeille de Brantôme, Oeuvres Completes (Paris: 1822), II, 56. This was at the battle of Aignadel, 14 May 1509. Fleurange further recorded of the King's activities that "all day the king showed high spirits and a good face, constantly going from company to company and from front to front, giving great courage to his men, by speaking encouraging words to them ..." (p.14). See also P. Jean-François Bonnefoy, ed., Chronique de l'Annonciade (Paris: 1937), p. 68; SaintGelais, Histoire de Louis XII. . . , p. 80.

15 Seyssel, Histoire de Louis XII. . . , p. 48; Saint-Gelais, quoted in the introduction to "Le Loyal Serviteur," Histoire du bon chevalier de Bayard (1476-1524), in C.B. Petitot, ed., Collection complète des mémoires relatifs a l'histoire de France (Paris: 1822), XVI, 90.

16 Jean Bouchet, Panegyrique de Louis de La Trémouille, (1460-1525), in Michaud et Poujoulat (Paris: 1857), IV, 438. See also Seyssel, Supplement, pp. 306-7, 310, and Bouchet's defence of La Tremouille in 1513, p. 457.

17 Girard, II, 1304.

18 Jean Bouchet, Les Annales d'Aquitaine (Paris: 1557), p. 194. See also Pierre de Bourdeille de Brantôme, Illustrious Dames of the Court of the Valois Kings, K.P. Warmeley, trans. (New York: 1912), p. 31; François de Belleforest, Les Grandes Annales et Histoire générale de France, des la venue des Francs en Gaule, jusques au regne de Roy tres-Chrestien de France et de Navarre Henri III (Paris: 1579), p. 1403.

19 Girard, II, 1272; Seyssel, Histoire de Louis XII..., p. 54. The reference to liquid gold was probably a joke directed to Louis' apparent stinginess, for which he was lampooned by comedians (Bibliotheque de l'Arsenal 3437, fol. 63).

20 Mézeray, p. 471; Saint-Gelais, Histoire de Louis XII. . ., pp. 31-2. 


\section{Renaissance et Réforme / 261}

21 Belleforest, p. 1403; Seyssel, Supplement, p. 164. For example, Louis encouraged Paul Émile (Langolius) to leave his native Italy for the French court, while Janus Lascuris-originally from Constantinople-served the King as his ambassador to Venice. During his sojourn at Pavia, Louis attended a lecture given by Jason Mainus, a noted professor of jurisprudence. As far as the King's personal taste in books was concerned, his favourite authors were Caesar and Cicero (Seyssel, Supplement, p. 164).

22 Bibliothèque Nationale Mss. Fr. 2924, fols. 29, 36 (Humbert Vellay, "Histoire particuliere de Louis XIIe, Roy de France”); Seyssel, Histoire de Louis XII . ., p. 23.

23 Alain Bouchart, Les Grandes Croniques de Bretaigne (Rennes: 1886), IV, 272-273 0 .

24 Seyssel, Histoire de Louis XII . . , pp.47-8; Saint-Gelais, Zeller, pt. IV, p. 49.

25 Quoted in A. L. Grant, The French Monarchy (1483-1789) (New York: 1970), Vol. 1; John S.C. Bridge, A History of France from the Death of Louis XI, (New York: 1978), IV, 266.

26 Girard, II, 1304.

27 Seyssel, Histoire de Louis XII . ., pp. 47-8.

28 B.A. 6315 , fol. 95; 3437, fol. 61; B.N. Mss. Fr. 2924, fol. 3 (Vellay); Archives Nationales M. 593, fols. 436-7 ("Dossier de La Trémouille"); Martin du Bellay, Mémoires, in Michaud et Poujoulat (Paris: 1857), V, 121; Seyssel, Supplement, p. 170.

29 Bouchet, La Trémouille, p. 437.

30 Francesco Guicciardini, The History of Italy, Sidney Alexander, ed. (New York: 1969), p. 121.

31 B.A. 3437 , fol. 61 .

32 B.A. 6315, fol. 95; B.N. Mss. Fr. 2924, fol. 10 (Vellay); Saint-Gelais, Histoire de Louis XII. . ., p. 114; Girard, II, p. 1263 ; Jean de Serres, Inventaire Général de l'Histoire de France (Paris: 1644), p. 357.

33 Commynes, p. 239.

34 It should be added, however, that Louis' choice of officers was not dictated solely by his eagerness to win general acceptance for his succession. Contemporaries immediately sensed that he exercised wisdom in choosing ministers who were both men of virtue and of small ambition.

35 Mézáray, p. 414; Brantôme, Illustrious Dames, p. 29.

36 B.N. Mss. Fr. 2924, fol. 3.

37 B.A. 3437 , fol. 68.

38 A.N. M593, fol. 381 ("Dossier de La Trémouille").

39 B.A. 3437, fol. 63; Seyssel, Histoire de Louis XII . . . p. 47; “Le Loyal Serviteur," p. 89.

40 d'Auton, IV, 26-7.

41 Seyssel, Histoire de Louis XII. . , p. 47.

42 Girard, II, 1300.

43 Quoted in Bouchet, La Trémouille, p. 440; Saint-Gelais, Zeller, pt. I, pp. 11 3-4.

44 Nicolo di Machiavelli, The Prince, in The Chief Works and Others, Allan Gilbert, trans. (Durham, North Carolina: 1965), I, 60.

45 Étienne Pasquier, Les Oeuvres d'Estienne Pasquier (Amsterdam: 1723), II, 344. A letter to the seigneur de Saincte-Marthe, c. 1589. See also Mézeray, p. 415; and Seyssel, Supplement, p. 305.

46 Saint-Gelais, quoted in the introduction to "Le Loyal Serviteur," p. 10.

47 Ibid., pp. 62-3.

48 B.N. Mss. Fr. 2924, fol. 49 (Vellay); Seyssel, Histoire de Louis XII . ., p. 44; Saint-Gelais, Histoire de Louis XII. . ., p. 176; d'Auton, IV, pp. 3-4.

49 Saint-Gelais, Zeller, pt. IV, p. 112.

50 Ibid. p. 113.

51 B.N. Mss. Fr. 2746, fol. 135 ("Contract de marriage du Roy Louis XII avec Anne de Bretaigne”); B.N. Collection Dupuy 581, vol. 135 ("Notice ancienne du procès de divorce"); B.A. 6315, fol. 


\section{2 / Renaissance and Reformation}

95("Histoire de Roi Louys douzième"); Bouchet, La Trémouille, p. 438; Father Daniel, The History of France (London: 1725), pp. 155-6; Bouchet, Aquitaine, p. 183; Bouchart, IV, 260 Jean Molinet, Chroniques de Jean Molinet, J.-A. Buchon, ed. (Paris: 1828), V, 101-2; "Le Loyal Serviteur," pp. 199-200; Girard, II, p. 1264; Nicole Gilles, Les Chroniques et Annales de France (Paris: 1566), II, cxxx; Machiavelli, The Prince, ChiefWorks, I, 28; Bonnefoy, ed., Annonciade, p. 70; P. Boucher, Mirouers et guydes fort propres pour les dames et demoiselles de France, qui seront de bonne volonté envers Dieu et leur salut, tout ainsi que ont esté les trés-illustres Princess, mdm. Jeanne de France, et Marguarite de Loreine, les vies desquelles seront mises au present volume (Bourges: 1585), p. 18; M. de Maulde La Clavière, Procedures Politiques du règne de Louis XII, vol. 81 in Collection de Documents inédits sur l'histoire de France (Paris: 1885), p. 1127.

52 B.N. Mss. Lat. 5973, vols. 46-9, 109-111 ("Procès de divorce"); B.N. Dupuy 581, fol. 135, 136, 137; B.N. Dupuy 347, fols. 110, 124; B.N. Mss. Fr. 2924, fols. 10-11 (Vellay); B.A. 6315, fol. 95; B.A. 3437, fol. 61; Bibliothèque Mazarine 1986, fols. 174-82 ("Procès et sentences de dissolution de marriage entre le Roy Louis XIIe et Madame Jeanne de France fille du Roy Louis XIe, 1498"); B.M. 2426, fol. 4 ("Annonciade"); De Coste, Éloges et vies..., vol. I, p. 41; Bonnefoy, ed., Annonciade, pp. 63, 69-70, 80; Seyssel, Histoire de Louis XII . ., pp. 27-8, 38-9; Saint-Gelais, Histoire de Louis XII . . , pp. 35, 36; Maulde La Clavière, "Interrogation et serment du Roi," p. 933; "Avis du Procureur Général du Parlement de Paris, en 1499, sur le divorce de Louis XII," pp. 1124-25; "Bulle d'Alexandre VI instituant le Tribunal, 29 Juillet 1498," pp. 874, 1125; "Notice ancienne du procès de divorce," pp. 1126-8; Bernard de Mandrot, ed., Journal de Jean de Roye, connu sous le nom de Chronique Scandaleuse, 1460-1483 (Paris: 1896), II, 161; Guicciardini, p. 139; Brantôme, Illustrious Dames, p. 216; Bouchet, La Trémouille, pp. 438-9; Mézeray, p. 418.

53 B.N. Dupuy 581, fol. 138; B.N. Mss. Lat. 5973, fol. 49; B.M. 1986, fols. 181-2 ("Dissolution du marriage . .."); Seyssel, Histoire de Louis XII . ., pp. 27-8; Saint-Gelais, Histoire de Louis $X I I$..., p. 136; Guicciardini, p. 139; Brantôme, Illustrious Dames, p. 216; Bouchet, La Tremouille, pp. 438-9; Mézeray, p. 418. The author of the Dupuy 581 ms. (fol. 138) added, however, that Louis never claimed that Jeanne was sterile, only that the deformity of her body prevented the act of consummation.

54 Maulde La Clavière, ed., "Bulle d'Alexandre VI,", p. 1125.

55 Boucher, Miouers et guydes..., p. 18.

56 De Coste, Éloges et vies, p. 41.

57 B.A. 3437 , fol. 61 .

58 Boucher, Miouers et guydes..., p. 18.

59 B.A. 3437 , fol. 61 ; B.N. Dupuy 581, fol. 135.

60 Brantôme, Illustrious Dames, pp. 29, 216.

61 B.N. Dupuy 581, fol. 136; B.A. 3437, fol. 61; Maulde La Clavière, ed., "Notice ancienne du procès de divorce," p. 1128.

62 B.N. Mss. Lat. 5973, fol. 112 ("Procès de divorce”); B.N. Dupuy 581, fol. 137; Maulde La Clavière, ed., "Declaration de Jeanne de France ... ," p. 835; and "Notice ancienne du procès de Divorce," p. 1129. There is a contradiction here. Some others reported that Jeanne declared that the marriage had been consummated. This seems even to be supported by the papal bull annulling the union (Maulde La Clavière, ed., "Bulle d'Alexandre VI ...," p. 814). Others maintained that the act had never committed, which was one of Jeanne's accusations against Louis (Bonnefoy, Annonciade, p. 88; Maulde La Clavière, ed., "Notice ancienne du procès de divorce," p. 1128).

63 Bonnefoy, ed., Annonciade, p. 80; Boucher, Mirouers et guydes, p. 19; Maulde La Clavière, ed., “Declaration de Jeanne de France...," p. 835.

64 Belleforest, pp. 1339-40. For the text of this treaty, see pp. 1340-2. In fact, Brittany was to keep its autonomous character, to be administered by Anne alone, and to pass after Anne's and Louis' death to their second child to do with as it wished, but recognizing the King of France as overlord. These conditions were written into Louis' and Anne's marriage contract. (B.N. Mss. Fr. 2746, fols. 134-137 ["Contract de marriage du Roy Louis XII avec Anne de Bretaigne, 1498”]; Seyssel 
Histoire de Louis XII .., p. 47).

65 B.M. 2426, fol. 5 ("Annonciade"); Bonnefoy, ed., Annonciade, p. 71; Boucher, Mirouers et Guydes, pp. 19-20.

66 Mézeray, p. 418; Nicolas Vignier, La Bibliothèque Historiale (Paris: 1588), III, 830.

67 B.N. Mss. Fr. 2924, fols. 13-14 (Vellay).

68 B.A. 6315 , fol. 96 ; B.N. Dupuy 231 , fols. $187-8$ ("Lettres concernant les offices de judicature"); Seyssel, Histoire de Louis XII . . . , pp. 2, 6; Saint-Gelais, Histoire de Louis XII . . . , pp. 123-4, 152; Mèzeray, p. 415; Pasquier, I, 83, 404; Bouchart, IV, 260vo-264; Serres, p. 351; Bouchet, Aquitaine, p. 183; Father Daniel, p. 155; Girard, II, 1263; Gilles, II, cxxx.

69 Saint-Gelais, quoted in the introduction to "Le Loyal Serviteur," p. 21.

70 Saint-Gelais, Histoire de Louis XII . . , p. 123.

71 Ibid.

72 Seyssel, Histoire de Louis XII. . , , p. 6.

73 Ibid., pp. 47-8.

74 Serres, p. 357.

75 B.A. 3437 , fol. 61 ; B.N. Dupuy 494, fols. $98-100$ ("Lettre relative aux monnaies de Bayonne, 1499”); B.N. Mss. Fr. 2924, fol. 2 (Vellay); Seyssel Histoire de Louis XII . . , pp. 2, 5, 6; Mèzeray, p. 415; Belleforest, p. 1338; Father Daniel, p. 154; Bouchet, Aquitaine, p. 183, and La Trémouille, p. 439; Gilles, II, cxxx.

76 Seyssel, Histoire de Louis XII . . , p. 49.

77 Mézeray, p. 415.

78 Belleforest, p. 1324; "Le Loyal Serviteur," p. 200; Pasquier, I, 404; Bouchet, Aquitaine, p. 183.

79 Gilles, II, cxxx. See also Pasquier, I, 404.

80 Pasquier, I, 404; Mézeray, p. 415.

81 "Le Loyal Serviteur," p. 202.

82 Ibid.

83 Ibid., pp. 13-4.

84 Girard, II, 1266. See also Seyssel, Supplement, p. 208.

85 Seyssel, Histoire de Louis XII . . , pp. 52-3 and Supplement, pp. 313-6.

86 Mèzeray, p. 415.

87 B.N. Mss. Fr. 2924, fols. 12-18 (Vellay); B.N. 6315, fol. 96; Serres, p. 357; Mézeray, p. 415; Bouchet, Aquitaine, p. 183; Bouchart, IV, 260 vo-261; Girard, II, 1263; Gilles, II, xccc.

88 B.N. Mss. Fr. 2924, fol. 42 (Vellay); B.A. 6315, fol. 105; Seyssel, Histoire de Louis XII . . . , p. 26; Saint-Gelais, Histoire de Louis XII . . , p. 121.

89 B.N. Mss. Fr. 2924, fol. 2 (Vellay); Seyssel, Histoire de Louis XIII . . . , pp. 2, 5; Saint-Gelais, Histoire de Louis XII . . , p. 122; Serres, p. 357; Belleforest, p. 1338; Father Daniel, p. 155; Girard, II, 1263; Gilles, II, cxxx.

90 Machiavelli, The Prince, I, 53-4; Familiar Letters, II, 925; The Discourses, I, 410; The Art of War, II, 584, 586, in Chief Works.

91 Seyssel, Histoire de Louis XII . . , pp. 3, 7, 25; d'Auton, III, 352.

92 Louis XII, Zeller, pt. IV, pp. 118-9.

93 Claude de Seyssel, La Monarchie de France, Jacques Poujol, ed. (Paris: 1961). Since the preparation of this paper, J.H. Hexter has translated this work into English: The Monarchy of France (New Haven, Connecticut: Yale University Press, 1981).

94 Seyssel, Histoire de Louis XII . . . , pp. 7, 25, 45, and Supplement, pp. 184-5.

95 Machiavelli, The Discourses, I, 237, 314, 422; The Prince, I, 70 in Chief Works.

96 Bouchet, La Trémouille, p. 442; Mėzeray, p. 429; D’Auton, III, pp. 335-40, 47; Fleurange, p. 41; Bouchart, IV, 274 ${ }^{\mathrm{vo}}$; Gilles, II, cxxxiij. 


\section{4 / Renaissance and Reformation}

97 Serres, p. 362; Bouchet, La Trémouille, p. 439; d'Auton, I, 143; Fleurange, p. 33; du Bellay, p. 114; Girard, II, 1268; Vignier, III, 842.

98 Fleurange, p. 32.

99 Ibid., p. 29.

100 Ibid., p. 32.

101 Mézeray, p. 430.

102 Guicciardini, pp. 279-80.

103 Father Daniel, p. 162; Fleurange, p. 33; Bouchet, Aquitaine, p. 186.

104 Belleforest, p. 1351. The revolt of Genoa (1506-7) was blamed solely on foreign intervention.

105 Ibid., p. 1356. To be fair to Louis, however, his reasons for the joint venture were sound. First, he did not trust Ferdinand and sought to tie him to a commitment from which he could not withdraw in order to interfere in French interests elsewhere. Second, the long French lines of supply and communication would be exceedingly vulnerable to assault-especially by Spain.

106 Mézeray, p. 424.

107 Ibid., pp. 429-30.

108 Machiavelli, The Prince, I, 18-20 in Chief Works.

109 B.N. Mss. Fr. 2924, fol. 41 (Vellay); Molinet, p. 185. According to Father Vellay, Louis himself recognized the gravity of the loss and took immediate steps to try to reduce it.

110 Girard, II, 1304.

111 Mézeray, p. 429.

112 Girard, II, 1330; Bouchart, IV, 281; Fleurange, p. 45.

113 Fleurange, Father Daniel and Guicciardini all attributed Louis' death to his weak constitution and dysentery with a high fever. Nor did the cold winter weather help the King's health, according to Fleurange. Fleurange and the "Loyal Serviteur" suggested that with the King's third marriage, his entire lifestyle had changed-he over-indulged, ignored his diet and stayed up very late. Father Daniel, D. Michel Felibien and Guicciardini were less subtle, suggesting that Louis was unable "to moderate his love for his new spouse ... ," and so fell ill and died "almost regretfully." De Coste shared this view. Finally, Francesco Vettori, the Florentine ambassador to Rome, cruelly reported that King Louis "had brought from England a 'hackney' so young, so beautiful, and so swift that she had ridden him right out of the world."

114 Quoted, Fleurange, p. 44. According to Hilarion de Coste, François did not like Louis at all even though the King had reared him in his house like a son (Éloges et vies, II, 161-2).

115 Ibid., p. 45.

116 Mézeray, quoted p. 472.

117 Louise de Savoie,Journal depuis 1476 jusqu'à 1522, in Michaud et Poujoulat (Paris: 1857), V, 89.

118 Ibid.

119 B.N. Cinq Cents de Colbert I, fols. 23-5, 60"o ("Extraict des Registres de Parlement-obseques de Louis XII"; "Les obseques du Roy Louis XII l'an 1514, registre de la cour de Parlement"); M. L. Cimber and F. Danjou, Archives Curieuses de l'Histoire de France, series I (Paris: 1835), II, 61-2; Fleurange, p. 45.

120 p. 89.

121 B.N. Mss. Fr. 2924, fol. 2 (Vellay).

122 pp. 44-5.

123 pp. 283-4.

124 Histoire de Louis XII..., pp. 129, 164, 184.

$125 \mathrm{IV}, 267^{\mathrm{vo}}$.

126 III, 879.

127 II, 1263. 
Renaissance et Réforme / 265

128 pp. $154,242$.

129 pp. $400,357,406$.

130 p. 1402.

131 Oeuvres, II, 56-7.

132 IV, 413, 471-2.

133 Supplement, pp. 316-7. Girard claimed that Louis was hardly liked by the people either because of his old age or because of his "great stinginess" while living, though his benign rule earned him his title as "Père du Peuple" at his death (II, p. 1331). 